DOI: $10.21802 / \mathrm{artm} .2021 .1 .17 .69$.

UDC 616.147.3-007.64:616-005.5-005.755-03

\title{
VENOUS HEMODYNAMICS IN ACUTE VARICOTHROMBOPHLEBITIS IN THE GREAT SAPHENOUS VEIN BASIN
}

\author{
S.S. Filip ${ }^{1}$, V.V. Rusyn ${ }^{2}$, I.I. Hadzheha ${ }^{1}$ \\ Uzhhorod National University, Medical Faculty, Uzhhorod, Ukraine: \\ ${ }^{1}$ Department of General Surgery, \\ ${ }^{2}$ Department of Surgical Diseases, \\ ORCID ID: 0000-0002-6549-3892, e-mail: filip.uz@i.ua, \\ ORCID ID: 0000-0003-4854-0228, \\ ORCID ID: 0000-0002-8916-8613, e-mail:hadzhehai@gmail.com
}

\begin{abstract}
Objective. To evaluate the influence of venous hemodynamics in acute varicothrombophlebitis in the basin of the great saphenous vein on the spread of the thrombotic process.

Materials and methods. The analysis of venous hemodynamic disorders in 245 patients with acute varicothrombophlebitis in the basin of the great saphenous vein was performed. The age of patients participating in the study ranged from 19 to 82 years (mean age 52 2 ,7 years). There were 93 men (38.0\%) and 152 women (62.0\%). The laboratory and instrumental methods were used for all the patients. They included doppler ultrasound and ultrasound duplex scanning. («ULTIMA PRO-30, zone Ultra», ZONARE Medical Systems Inc., USA).

Results. When AVTF occurred in the GSV basin, all patients showed reflux in the superficial veins of the lower extremities. The ultrasound scanning was performed at the initial examination and immediately before urgent surgery for AVTF. The data of color duplex mapping allowed to reveal certain regularities of venous blood flow disturbance in AVTF and divided patients depending on the state of venous blood flow in the GSV basin into 5 groups. Each of these groups of patients, depending on the prevalence of venous reflux in the GSV pool, was divided into two subgroups: local and widespread reflux. It should be noted, that the conditions for the detection of total reflux in ATVF, with the involvement of GSV in the pathological process, were not due to thrombotic lesions of the latter. When venous reflux was detected, the elasticity and extensibility of the vein wall at the apex of thrombotic masses were evaluated. The ratio of the diameters of the GSV in these positions and the assessment of the "degree of elasticity" by Schwalb PG (2005), which indirectly characterized the state of venous tone were calculated. Venous reflux was assessed on a Valsalva test in vertical and horizontal positions. Venous reflux of blood in the femoral veins was found in $134(54.7 \%)$ patients. At the same time, local reflux was found in 38 (15.5\%), and widespread - in 96 (39.2\%) patients. It should be noted that the prevalence of venous reflux was directly proportional to its power. Among all groups of patients with acute varicothrombophlebitis, $176(71.8 \%)$ had widespread reflux in the great saphenous vein and $96(39.2 \%)$ in the femoral vein. In $37(15.1 \%)$ patients with acute varicothrombophlebitis revealed a combined nature of reflux, ie the spread of reflux from the superficial venous system not only to the apex of thrombotic masses, but also to the site of horizontal perforation, and reflux from the deep venous system spread through failed perineal veins in the great saphenous vein. Thus, widespread venous reflux was found in $87.3 \%$ of patients. In the absence of vertical reflux through the sapheno-femoral cochlea and the presence of an ascending process of thrombosis, it is necessary to identify another source of reflux.

Conclusions. It is proved that the process of thrombosis in acute varicothrombophlebitis depends on the power of venous reflux, the severity of venous discharge through the communicating veins, the state of collateral venous blood flow in venous shunts and basins of large and small subcutaneous venous blood vessels. Venous reflux in the trunk of the great saphenous vein to some extent determines the embolism of the thrombus and participates in its development. Varicose veins of the great saphenous vein and the discharge of blood through incapable permeable veins reduce the power of reflux through the sapheno-femoral cochlea and reduce the rate of thrombosis in the main trunk.
\end{abstract}

Keywords: acute varicothrombophlebitis, venous hemodynamics, the great saphenous vein, venous reflux.

Introduction. During life, acute varicothrombophlebitis (AVTP) is observed in $20-40 \%$ of the world's population. According to American authors, up to 125,000 new cases of acute superficial thrombophlebitis are registered in the United States each year [1-3]. At the same time, in $85-95 \%$ of all patients the cause of acute superficial thrombophlebitis is varicose disease of the lower extremities [1, 4-6]. In $5.0-15.0 \%$ of patients, thrombophlebitis occurs on the background of varicose transformation of superficial veins due to postthrombophlebitis syndrome or in the absence of any signs of varicose veins. Every second patient with varicose veins has at least one episode of varicothrombophlebitis during their lifetime. At the same time, any form of thrombophlebitis can be a primary manifestation of systemic or cancer [5].

The most common localization of thrombotic lesions in AVTP is the basin of the great saphenous vein (GSV), which is involved in the pathological process in $60.0-80.0 \%$ of cases [5,7,]. Despite this prevalence, most surgeons consider AVTP a disease that rarely causes complications [8]. Considering that the thrombotic process rarely extends to the deep venous system, and the question of the transition of thrombotic lesions from the superficial 
veins to the deep venous system through the failing perforated veins is generally little studied.

The question of choosing a method of treatment of acute varicothrombophlebitis remains debatable. Most authors prefer conservative treatment. Even the authors who prefer surgical treatment have no data on the study of venous hemodynamics in acute varicothrombophlebitis in order to substantiate the pathogenetic indications and contraindications to surgical treatment of the latter.

Objective. To evaluate the influence of venous hemodynamics in acute varicothrombophlebitis in the basin of the great saphenous vein on the spread of the thrombotic process.

Materials and methods. Based on the data of ultrasound examination, the analysis of venous hemodynamic disorders in 245 patients with acute varicothrombophlebitis in the basin of the great saphenous vein was performed. Of these, $93(38.0 \%)$ were men and $152(62.0 \%)$ were men. The age of patients ranged from 19 to 82 years, the mean age was $52 \pm 2.7$ years.

Laboratory research methods were used to examine patients, as well as instrumental: doppler ultrasound and duplex ultrasound scanning («ULTIMA PRO-30, z.one Ultra», ZONARE Medical Systems Inc., USA).

Results and their discussion. The process of thrombosis in the occurrence of AVTP depends on the power of venous reflux, the severity of venous discharge through the communicating veins, the state of collateral venous blood flow in venous shunts and basins of great and small subcutaneous veins, the state of venous blood flow in the deep vena cava. All these processes, individually or together, have a pronounced effect on the process of thrombosis, increasing or decreasing the latter. The danger of venous reflux is the acceleration of venous blood flow, the inability to fix the thrombotic masses to the venous wall and the formation of a floating embolic-dangerous apex of thrombotic masses.

The only reliable non-invasive method of diagnosing venous blood flow in the lower extremity is ultrasound, which allows with almost $100 \%$ probability to obtain objective information.

When AVTP occurred in the GSV pool, all patients showed reflux in the superficial veins of the lower extremities. At the height of the Valsalva test, in horizontal and vertical positions of the body, depending on the change in the diameter of one of the fragments of the GSV trunk by $1-2 \mathrm{~cm}$ proximal to the apex of thrombotic masses, the severity of venous reflux was assessed. The study was performed at the initial examination and immediately before the emergency surgery for AVTP (Fig. 1).

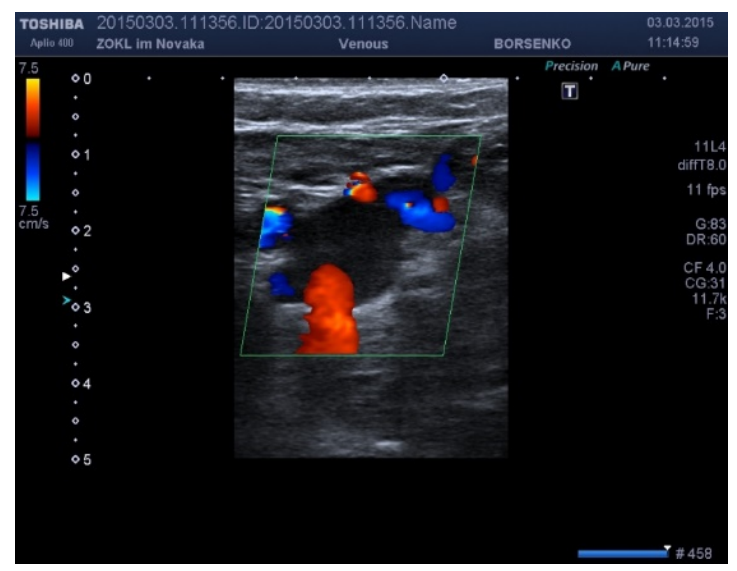

Fig. 1. Ultrasound photo: failure of the ostial valve of the great saphenous vein during color mapping

The data of color duplex mapping allowed to identify certain patterns of venous blood flow during AVTP and to divide patients depending on the state of venous blood flow in the GSV basin into several groups:

- Group I - patients in whom the proximal limit of thrombotic masses reached the external iliac vein (3 patients);

- Group II - patients with a thrombus apex in the common femoral vein (11 patients);

- Group III - localization of the proximal border of thrombotic masses at the level of the upper third of the thigh (122 patients);

- Group IV - localization of the proximal border of thrombotic masses at the level of the lower third of the thigh (55 patients);

- Group V - thrombotic masses reached the upper third of the leg (54 patients).

Each of the groups of patients, depending on the prevalence of venous reflux in the GSV basin, was divided into two subgroups: local and widespread reflux (Table 1).

Frequency of reflux in superficial and deep venous systems of the lower extremity in patients with acute varicothrombophlebitis

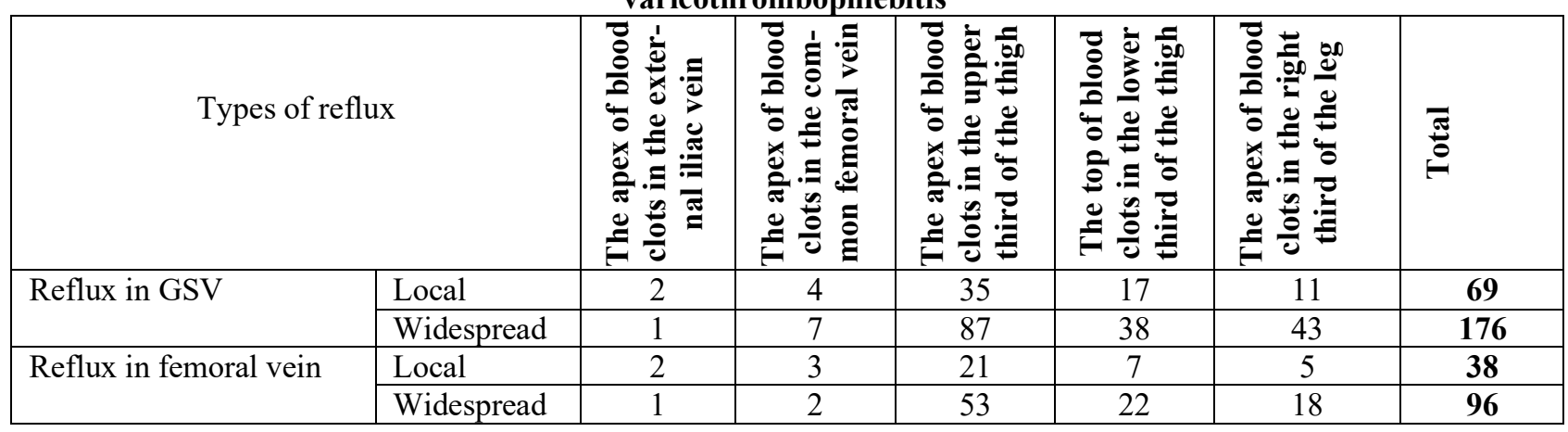


It should be noted that the conditions for the detection of total reflux in ATVP, with the involvement of GSV in the pathological process, were not due to thrombotic lesions of the latter. When reflux was detected in the femoral vein, two groups of patients were singled out: - - with preserved valve function or valvular insufficiency of I - II degree and local reflux;

- $\quad$ - Failure of valves of the III degree and widespread reflux.

Examination of patients revealed that only 69 (28.2\%) patients had local venous reflux in GSV against $176(71.8 \%)$ patients with diffuse reflux. Thus, in $71.8 \%$ of patients with regardless of the location of the apex of thrombotic masses, common venous reflux in the GSV pool reached the apex of the thrombus (Fig. 2).

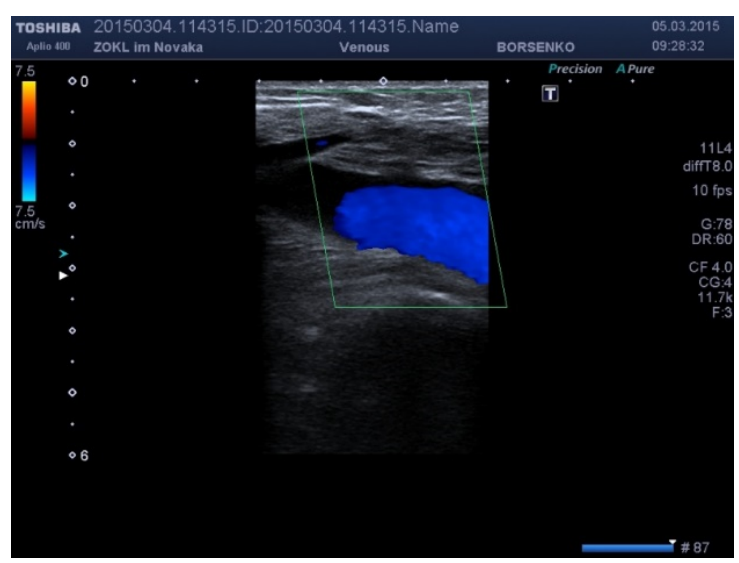

Fig. 2. Ultrasound photo: venous reflux in the great saphenous vein during color mapping

Venous reflux of blood in the femoral veins was found in $134(54.7 \%)$ patients. At the same time, local reflux was found in $38(15.5 \%)$, and widespread - in 96 $(39.2 \%)$ patients. It should be noted that the prevalence of venous reflux was directly proportional to its power.

Thus, among all groups of patients with AVTP, $176(71.8 \%)$ had widespread reflux in GSV and 96 $(39.2 \%)$ in the femoral vein. In $37(15.1 \%)$ patients with AVTP revealed a combined nature of reflux, namely the spread of reflux from the superficial venous system not only to the apex of thrombotic masses, but also to the site of horizontal perforation, and reflux from the deep venous system spread through failed perineal veins GSV. Thus, widespread venous reflux was found in $87.3 \%$ of patients.

When venous reflux was detected, the elasticity and extensibility of the vein wall at the apex of thrombotic masses were evaluated. Calculated the ratio of the diameters of the GSV in these positions and the assessment of the "degree of elasticity" by Schwalb PG (2005), which indirectly characterized the state of venous tone. According to the literature, the index of elasticity for the common femoral vein in healthy individuals is 1.37 . It was found that the coefficient of elasticity $\geq 1.45$ is a predictor of the development of varicose veins.

Venous reflux was assessed on a Valsalva test in vertical and horizontal positions. Evaluation of the obtained results showed that orthostatic dilatation quantitatively differed in vertical and horizontal positions. It was found that the diameter of the common femoral vein normally increased by no more than $1 / 3$, and in the case of valvular failure of the superior venous segment - by $1 / 2-2 / 3$. When performing the Valsalva test, to study the failure of the valvular apparatus of the veins of the lower extremities, objectively considered a time interval of at least 10 seconds.

The diameter of the GSV trunk at AVTP depended on the prevalence of reflux (Table 2).

Table 2

Dependence of the diameter of the trunk of the great saphenous vein and the elasticity index on the prevalence of venous reflux $(\mathbf{p} \leq \mathbf{0 , 0 1})$

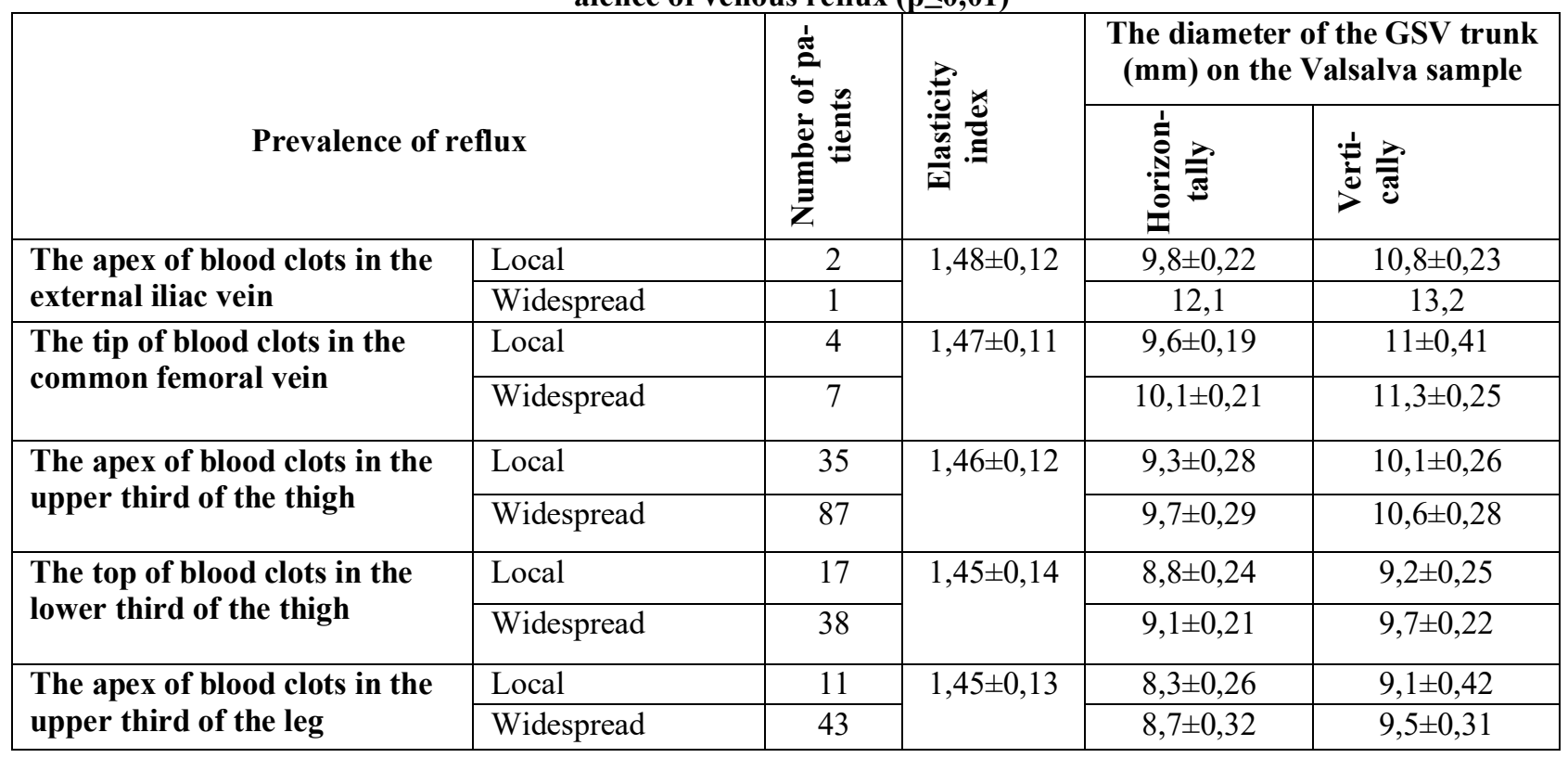

With local venous reflux, as a rule, observed the preservation of "elasticity", tone and ability of the venous wall to contract, as evidenced by the diameter of the vein, which corresponds to the original when returning to a horizontal position. Changes in the diameter of the vein in the range of $2.3-2.5 \mathrm{~mm}$ during the hydrodynamic test of 
Valsalva indicated a partial lesion of the muscular membrane of the vein.

The data obtained indicate that with local venous reflux, the elastic properties of the venous wall and the tendency to spasm in front of the apex of the thrombus are preserved. Therefore, the preserved tone of the venous wall prevents further growth of the thrombus. The combination of opposite factors, in particular thrombus dilation and venous spasm, contribute to the formation of occlusive thrombosis, which in turn slows down the growth of the thrombus and reduces its embolic properties.

At a local reflux at the level of the lower third of a hip at any patient failure of penetrating veins of a shin was not found. This was evidence of the lack of conditions for the transition of the thrombotic process through the penetrating veins of the tibia into the deep venous system.

An increase in the proximal border of thrombotic lesions, in the absence of local venous reflux in GSV on the top of thrombotic masses during ultrasound monitoring for 1 - 2 days in patients of groups III - V, was observed in only $8(3.5 \%)$ of 231 patients. The apex of the thrombus was localized in the lower third of the thigh $(n=3)$ and the upper third of the leg $(n=5)$. It is noted that the increase in the limit of thrombotic masses, with the localization of thrombotic lesions in the lower third of the thigh and upper third of the leg, per day averaged $14.1 \pm 1.82 \mathrm{~mm}(\mathrm{p} \leq 0.01)$ and $11.8 \pm 1.72 \mathrm{~mm}(\mathrm{p} \leq 0.01)$, respectively. Collateral venous blood flow in patients III - V groups was registered in $5(2.2 \%)$ of 231 patients in the upper third of the thigh, but it did not affect the rate of growth of thrombotic masses.

When analyzing the size of the diameter of the GSV trunk above the apex of the thrombus, it was found that the diameter of the GSV trunk was directly proportional to the location of the apex of thrombotic masses, the prevalence of venous reflux and the patient's position. Thus, in the most numerous group of patients with widespread venous reflux, the diameter of the GSV trunk above the apex of thrombotic masses in the horizontal position was $9.7 \pm 0.29 \mathrm{~mm}(\mathrm{p} \leq 0.01)$, and vertically at the height of the Valsalva test $-10.6 \pm 0.28 \mathrm{~mm}(\mathrm{p} \leq 0.01)$. The elasticity index was $1.46 \pm 0.12(\mathrm{p} \leq 0.05)$. When re-transitioning to the horizontal position, the diameter of the GSV returned quite slowly to the original. All these indicators indicate a pronounced damage to the muscular layer of the venous wall, reducing its tone and elasticity, which affects the contractile function of the vein.

When returning to the horizontal position, the diameter of the GSV returned very slowly to the original. The results indicate severe damage to the muscular membrane of the vein, a decrease in its tone and elasticity, which affected its contractility. The venous wall has almost no resistance to the masses, the vein increases in diameter, especially in the area of varicose ectasia growth of thrombotic, i.e. in places where the venous wall is most destroyed.

In 5 patients with widespread venous reflux in the trunk of the GSV found thrombosed perforated veins on the leg. Ultrasound examination of the tibial veins in patients with local venous reflux at the level of the upperlower third of the thigh revealed their full functionality and served as evidence of the impossibility of the transition of the thrombotic process to deep veins in this category of patients..

Ultrasound examination during the day of the proximal thrombus border in patients of groups IV and V revealed an increase in thrombus in $74(91.4 \%)$ of 81 patients with diffuse reflux against $2(7.1 \%)$ of 28 patients with local reflux. That is, the frequency of proximal thrombosis in diffuse reflux was almost 13 times higher than in local. The increase in the peak of thrombotic masses during the day in patients of groups IV and $\mathrm{V}$ with diffuse and local venous reflux was $28.9 \pm 2.4$ and $15.7 \pm 1.8 \mathrm{~mm} /$ day (p,00.01), respectively, i.e. in 1,8 times faster with widespread reflux.

Thus, in ascending AVTP, the relationship between the apex of thrombotic masses and venous reflux is clearly visible. In addition, in reflux, venous blood flow, which reaches the apex of the thrombus, expands the diameter of the vein and prevents it from fixing to the wall of the latter. This situation contributes to the formation of a floating embolus apex. That is, venous reflux in the trunk of the GSV to some extent determines the embolism of the thrombus and participates in its development.

In the absence of vertical reflux through the sapheno-femoral cochlea and the presence of an ascending process of thrombosis, it is necessary to identify another source of reflux.

The rate of proximal growth of thrombotic lesions in patients of groups IV and V was also influenced by intense retrograde blood flow in the upper varicose stem and tributaries of GSV. Collateral blood flow reduced the power of venous reflux, thereby reducing its effect on the rate of thrombosis. The slower growth rate of the proximal thrombosis border also depends on the pathological discharge of blood due to the failure of the penetrating veins of Dodd and Gunter, which reduces the severity of reflux and its effect on the apex of the thrombus. Failure of the penetrating veins in the lower third of the thigh was found in $18(16.5 \%)$ of 109 patients of groups IV and V. The penetrating veins had a diameter of $6.7 \pm 1.6 \mathrm{~mm}(\mathrm{p} \leq 0.01)$. In this case, the horizontal reflux through the incapable penetrating veins in the lower third of the thigh passed to the femoral vein, and from the femoral vein through the incapable ostial valve blood again entered the trunk of the GSV (Fig. 3).

Pathological circulation of venous blood caused phlebohypertension in this area and due to the excess volume of venous blood contributed to the development of valvular failure of the I - II degree in the femoral vein. A defective circle of venous circulation was formed.

In $8(7.3 \%)$ of 109 patients the development of venous circulation due to involvement in the process of varicose vein Giacomini, which is combined with the trunk of the GSV through the sapheno-femoral cotyledon, and with the popliteal vein through the sapheno-popliteal cotyledon. Venous blood discharge through the Giacomini vein was accompanied by venous return through the popliteal and femoral veins. 


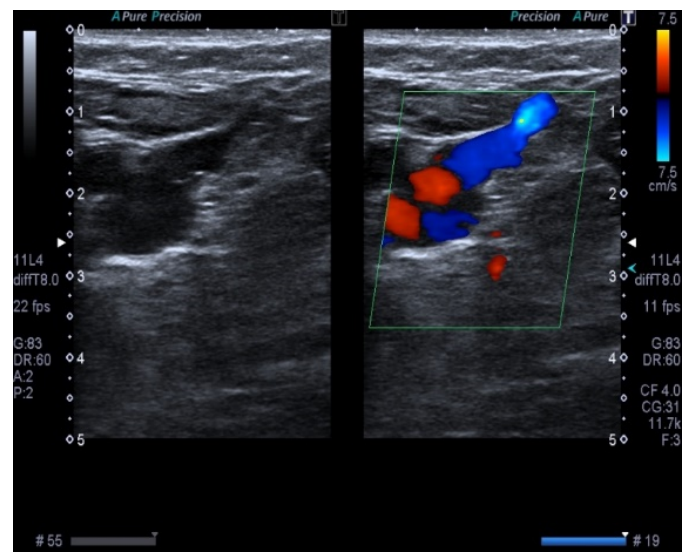

Fig. 3. Ultrasound lattice failure of the ostial valve of the great saphenous vein

Elimination of the venous circulation defect increases the power of widespread venous reflux in GSV and the rate of thrombus apex growth, but the thrombotic process did not extend to the permeable permeable veins. While maintaining the function of the ostial valve of the GSV and the normal diameter of the GSV on the thigh, the ascending AVTP on the lower leg in no case led to the emergence of a floating apex in the upper third of the leg or the lower third of the thigh.

Thus, the prevalence of venous reflux, collateral venous blood flow and blood flow through the penetrating veins in one or two venous subcutaneous basins (GSV and SSV), as well as between the superficial and deep veins of the lower extremity affect the rate of thrombosis, accelerating or slowing down.

\section{Conclusion:}

1. The direction of the thrombotic process in the great saphenous vein is towards venous reflux.

2. The power of venous reflux in the great saphenous vein is influenced by its prevalence, due to the destruction of the valvular apparatus, and the diameter of the trunk of the latter.

3. In the event of a thrombus outside the area of influence of venous reflux, the growth of the latter slows down.

4. Distinguished venous reflux prevents the fixation of thrombotic masses to the vein wall and promotes the formation of a floating embolic apex.

5. Varicose veins of the great saphenous vein and the discharge of blood through the incapable penetrating veins reduce the power of reflux through the sapheno-femoral coronary artery and reduce the rate of thrombosis in the main trunk.

\section{References:}

1. Zolotukhin IA, Gavrilov SG, Kirienko AI. Phlebology today. Annaly khirurgii (Annals of Surgery, Russian journal). 2016; 21(1-2):19-25. DOI: 10.18821/15609502-2016-21-1-19-252. URL: https://cyberleninka.ru/article/n/flebologiya-segodnya

2. Rusyn VI, Korsak VV, Popovych YaM, Levchak YUA, Holovatsky AS. Prevention of venous thromboembolic complications in transfascial thrombosis of the lower extremities.Galician Medical Journal. 2016; 23(2):42-5. URL: http://nbuv.gov.ua/UJRN/glv_ 2016_23_2_15

3. Chernukha LM, Shchukin SP. Thrombotic complications in severe forms of varicose disease: diagnosis, surgical treatment, using miniinvasive methods. Klinicheskaia khirurgiia. 2015; 1:35-7. URL: http://www.irbis-nbuv.gov.ua/cgi-bin/ir-

bis nbuv/cgiir-

bis_64.exe? $21 \mathrm{DBN}=\mathrm{LINK} \& \mathrm{P} 21 \mathrm{DBN}=\mathrm{UJRN} \& Z 21 \mathrm{I}$ $\mathrm{D}=\& \mathrm{~S} 21 \mathrm{REF}=10 \& \mathrm{~S} 21 \mathrm{CNR}=20 \& \mathrm{~S} 21 \mathrm{STN}=1 \& \mathrm{~S} 21 \mathrm{~F}$ $\mathrm{MT}=\mathrm{ASP}$ meta\&C21COM=S\&2_S21P03 $=\mathrm{FILA}=\& 2$ $\mathrm{S} 21 \mathrm{STR}=\mathrm{K} 1 \mathrm{Kh} 2015 \quad 111$

4. Savelyev VS, Kïrienko ĀI. Vascular surgery: a national guide (short edition). M.: GEOTAR-Media. 2015. P.464.

5. Rusyn VI, Korsak VV, Popovych YaM. Surgical treatment of thrombosis of the inferior vena cava: a monograph. Uzhhorod: Carpathians. 2017. Р.360. вкл. ISBN 978-966-2095-53-1

6. Kostiv SYa. Postoperative acute thrombophlebitis surgical treatment. Hospital Surgery. Journal Named by L.Ya. Kovalchuk. 2014; 65(1):43-4. https://doi.org/10.11603/1681-2778.2014.1.4360.

7. Kirienko AI, Panchenko EP, Andriyashkin VV. Venous thrombosis in the practice of a physician and surgeon. M.: Planida. 2012. P.336. URL: http://www.noat.ru/docs/tromboz.pdf

8. Popovich YaM. Evaluation of hemodynamic parameters in patients with trombosis inferior vena cava system dependent on the treatment method. Surg Ukr [Internet]. 2018; May, 17;(1):55-61. URL: http://surgukraine.com.ua/article/view/SU2018155

\section{УДК 616.147.3-007.64:616-005.5-005.755-03 \\ ВЕНОЗНАЯ ГЕМОДИНАМИКА ПРИ ОСТРОМ ВАРИКОТРОМБОФЛЕБИТЕ В БАССЕЙНЕ БОЛЬШОЙ ПОДКОЖНОЙ ВЕНЫ}

\author{
С.С. Филип ${ }^{1}$, В.В. Русин ${ }^{2}$, И.И. Гаджега ${ }^{1}$ \\ Ужггородский национальный университет, \\ медиичинский факультет, г. Ужсгород, Украина: \\ ${ }^{1}$ кафедра общей хирургии, \\ ${ }^{2}$ кафедра хирургических болезней, \\ ORCID ID: 0000-0002-6549-3892, \\ e-mail: filip.uz@i.ua, \\ ORCID ID: 0000-0003-4854-0228, \\ ORCID ID: 0000-0002-8916-8613, \\ e-mail: hadzhehai@gmail.com
}

Резюме. Цель исследования. Оценить влияние венозной гемодинамики при остром варикотромбофлебите в бассейне большой подкожной вены на распространение тромботического процесса.

Материалы и методы исследования. В работе проведен анализ нарушений венозной гемодинамики в 245 пациентов с острым варикотромбофлебитом в бассейне большой подкожной вены. Среди них было 93 (38,0 \%) мужчин и 152 (62,0 \%) женщины. Возраст больных составлял от 19 до 82 лет, средний возраст $-52 \pm 2,7$ лет. Для обследования больных применили лабораторные методы исследования, а также инструментальные: ультразвуковую допплерографию и ультразвуковое дуплексное сканирование. 
Результаты исследований. Среди всех групп больных с ГВТФ в 176 (71,8 \%) выявлены распространенный рефлюкс в БПВ и в $96(39,2 \%)$ в бедренной вене. В 37 (15,1%) пациентов с ГВТФ обнаружено совмещенный характер рефлюкса, то есть распространение рефлюкса с поверхностной венозной системы не только к верхушке тромботических масс, но и к месту формирования горизонтального прободающего, а рефлюкс с глубокой венозной системы распространялся через несостоятельные прободающие вены в БПВ. Таким образом, распространенный венозный рефлюкс обнаружили в 87,3\% больных. При отсутствии вертикального рефлюкса через сафено-феморального соустье и наличии восходящего процесса тромбообразования необходимо выявить другой источник рефлюкса.

Выводы. Доказано, что процесс тромбообразования при возникновении острого варикотромбофлебита зависит от мощности венозного рефлюкса, выраженности венозного сброса через коммуникантные вены, состояния коллатерального венозного кровотока в вено-венозных шунтах и бассейнах большой и малой подкожных вен, состояния венозного кровотока в глубокой венозной системе нижних конечностей. Венозный рефлюкс в стволе большой подкожной вены в той или иной степени определяет ембологенность тромба и принимает участие в его развитии.

Ключевые слова: острый варикотромбофлебит, венозная гемодинамика, большая подкожная вена, венозный рефлюкс.

\section{УДК 616.147.3-007.64:616-005.5-005.755-03 \\ ВЕНОЗНА ГЕМОДИНАМІКА ПРИ ГОСТРОМУ ВАРИКОТРОМБОФЛЕБІТІ У БАСЕЙНІ ВЕЛИКОЇ ПІДШКІРНОЇ ВЕНИ}

С.С. Філіп ${ }^{1}$, В.В. Русин ${ }^{2}$, I.І. Гаджега ${ }^{1}$

Ужсгородський національний університет, медичний факультет, м. Ужгород, Україна:

${ }^{I}$ кафедра загальної хірургії,

${ }^{2}$ кафедра хірургічних хвороб,

ORCID ID: 0000-0002-6549-3892,

e-mail:filip.uz@i.ua,
ORCID ID: 0000-0003-4854-0228,

ORCID ID: 0000-0002-8916-8613,

e-mail:hadzhehai@gmail.com

Резюме. Мета дослідження. Оцінити вплив венозної гемодинаміки при готрому варикотромбофлебіті у басейні великої підшкірної вени на поширення тромботичного процесу.

Матеріали та методи дослідження. У роботі проведено аналіз порушень венозної гемодинаміки у 245 пацієнтів 3 гострим варикотромбофлебітом у басейні великої підшкірної вени. 3 них було 93 (38,0 \%) чоловіків та 152 (62,0\%) жінок. Вік хворих становив

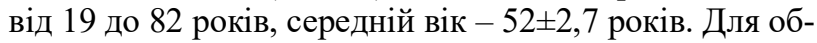
стеження хворих застосували лабораторні методи дослідження, а також інструментальні: ультразвукову доплерографію та ультразвукове дуплексне сканування.

Результати досліджень. Серед всіх груп хворих з ГВТФ у $176(71,8 \%)$ виявлено розповсюджений рефлюкс у ВПВ та в 96 (39,2 \%) у стегновій вені. У 37 $(15,1 \%)$ пацієнтів з ГВТФ виявлено поєднаний характер рефлюксу, тобто поширення рефлюксу з поверхневої венозної системи не лише до верхівки тромботичних мас, але й до місця формування горизонтального пронизного, а рефлюкс з глибокої венозної системи поширювався через неспроможні пронизні вени у ВПВ. Таким чином, розповсюджений венозний рефлюкс виявили у 87,3 \% хворих. При відсутності вертикального рефлюксу через сафено-феморальне співгирло і наявності висхідного процесу тромбоутворення необхідно виявити інше джерело рефлюксу.

Висновки. Доведено, що процес тромбоутвоерння при виникненні гострого варикотромбофлебіту залежить від потужності венозного рефлюксу, вираженості венозного скиду через комунікантні вени, стану колатерального венозного кровоплину у веновенозних шунтах та басейнах великої та малої підшкірних вен, стану венозного кровоплину у глибокій венозній системі нижньої кінцівки. Венозний рефлюкс у стовбурі великої підшкірної вени у тій чи іншій мірі визначає ембологенність тромбу та бере участь у його розвитку.

Ключові слова: гострий варикотромбофлебіт, венозна гемодинаміка, велика підшкірна вена, венозний рефлюкс.

Стаття надійшла в редакцію 28.12.2020 р. 